\title{
A Multivariate Investigation of Overall Happiness, Job Satisfaction and Income Satisfaction of Women and Men in Turkey
}

Asl ERMIŞ-MERT (https://orcid.org/0000-0001-5599-3407), Department of Sociology, Koç University, Turkey; e-mail: amert@ku.edu.tr

\section{Türkiye'de Kadın ve Erkeklerin Mutluluk, İş Tatmini ve Gelir Tatmininin Çok Değişkenli Bir Analizi}

\begin{abstract}
This paper examines the factors affecting working women's and men's overall happiness, job satisfaction and income satisfaction levels and the association between these three measures of happiness. Women and men who are satisfied with their workplace relations relative to those who are not are more likely to report that they are satisfied or very satisfied with their life, job and income. Women's job and income satisfaction and men's all three means of happiness are more likely to be high for those who received a pay rise last year. The strongest correlation is observed between job satisfaction and income satisfaction for both genders, which is slightly stronger for women that challenges the arguments on women's financial motivation to be not as strong as men at work. Spillover hypothesis is confirmed in all pairwise combination of the three happiness measures according to findings.
\end{abstract}

Keywords $\quad$ : Gender and Employment, Happiness, Job Satisfaction, Pay Satisfaction, Multivariate Probit Regression.

JEL Classification Codes : $\quad$ C3, I31, J28.

\section{Öz}

Bu çalışma, çalışan kadınların ve erkeklerin yaşam, iş ve gelir tatmin düzeylerini etkileyen faktörleri Türkiye bağlamında irdelemekte ve bu öğeler arasındaki korelasyonu incelemektedir. Araştırmanın bulguları, işyeri ilişkilerinden memnun olan kadınların ve erkeklerin yaşam, iş ve gelir tatmin düzeylerinin yüksek olma eğiliminin daha fazla olduğunu göstermiştir. Kadınların iş ve gelir, erkeklerin ise her üç mutluluk öğesi önceki sene alınan gelir artışından pozitif olarak etkilenmektedir. En yüksek korelasyon seviyesi kadınlar için biraz daha güçlü olmak üzere iş ve gelir tatmini arasında görülmüş, bu bulgu kadınların iş hayatında ekonomik kazanımlara erkekler kadar önem vermedikleri argümanının aksini desteklemiştir. Yayılma hipotezi üç mutluluk öğesinin tüm ikili kombinasyonlarında gözlemlenmiştir.

Anahtar Sözcükler : Toplumsal Cinsiyet ve İstihdam, Mutluluk, İş Tatmini, Gelir Tatmini, Çok Değişkenli Probit Regresyonu. 
Ermiş-Mert, A. (2020), “A Multivariate Investigation of Overall Happiness, Job Satisfaction and Income Satisfaction of Women and Men in Turkey", Sosyoekonomi, Vol. 28(44), 11-26.

\section{Women's and Men's Overall Happiness, Job Satisfaction and Income Satisfaction}

Examining overall happiness of working individuals independently of their job and income satisfaction is challenging. Although these are not mutually inclusive at an absolute level, they are expected to be considerably interrelated. This article sets out to investigate the relationship between overall happiness, job satisfaction and income satisfaction levels of working women and men in Turkey, and components that affect these means of happiness.

While the concept of life satisfaction may be different than happiness, they are highly related ( $\mathrm{Ng}, 2015)$, and a strong positive correlation is found between them (Medvedev \& Landhuis, 2018). Although it should be underlined that these are indeed not synonymous concepts, in the questionnaire analysed in this study (Turkish Statistical Institute - TurkStat, 2016), life satisfaction is measured via asking individuals how happy they are. Therefore, considering that job and income satisfaction are measured through asking respondents their satisfaction levels, to discuss the three concepts (overall happiness, life satisfaction and income satisfaction) together, life satisfaction and overall happiness will correspond to each other at times in the context of this paper. In addition, while income is generally recognized as a component of job satisfaction, income satisfaction will be evaluated as an independent determinant of happiness in this study, considering the need to examine these individually as well as in relation to each other.

The analysis will be conducted separately for women and men. In the literature, it is widely argued that women are more satisfied with their jobs than men (Groot \& van den Brink, 2000; Huang \& Gamble, 2015; Zou, 2015). Clark (1997) argues that while women and men with identical jobs and expectations tend to claim equal levels of job satisfaction, women's satisfaction levels are higher overall despite holding less satisfying jobs due to their expectations being lower than men because of their relatively disadvantaged circumstances. On the other hand, Chiu (1998) states that professional women's job satisfaction levels are lower, which is a result of the inequalities in opportunities, and they do have the same expectations as professional men in their case study on lawyers. SousaPoza and Sousa-Poza (2000) point out that women are much more satisfied at work when their work-role outputs (e.g. pay) are considerably higher relative to men. However, their findings present that in most countries when different work-role inputs and outputs are controlled for, no significant gender differences in job satisfaction exist.

As aforementioned, income is one of the components that is mostly considered as a determinant of job satisfaction. In the literature, the relationship between overall happiness, job satisfaction and income are extensively discussed in general and based on gender. Loewe et al. (2014) find that in Chile, when age and gender are controlled for, satisfaction with one's financial situation is found to be the dominant predictor of workers' overall life satisfaction. O'Donnell (2015) argues that absolute income is not significantly related to job satisfaction yet relative income as well as opinions on social class affect individuals' work satisfaction greatly. For women, the correlation between life/job satisfaction and income are found to be low in various contexts. Mayraz et al. (2009) indicate that life satisfaction of 
men is significantly correlated with their relative (generically rather than in comparison to close others) income, but this is not the case for women. Huang and Gamble (2015) state that pay is a significant determinant of male employees' job satisfaction but does not seem to be a good indicator of women's job satisfaction. Similarly, Zou (2015) finds that men value pay more than women working both in part-time and full-time jobs. Also, Groot and van den Brink (2000) suggest that absolute and relative wages affect men's job satisfaction but not women's job satisfaction. In terms of expectations concerning income, Demirel and Y1ldirım (2015) indicate that as pay rise and financial benefits are seen as valuable incentives by both women and men, women's expectations of pay are lower.

Regarding the relationship between life and job satisfaction, there are three main hypotheses presented in the literature: spillover, compensation and segmentation hypothesis (Dolan \& Gosselin, 2000; Strauser, 2014; Unanue et al., 2017). Strauser (2014) states that spillover hypothesis refers to a positive correlation between life and job satisfaction as in one part of life affecting the other, compensation hypothesis indicates a negative correlation between life and job satisfaction in terms of making up for the lack of satisfaction in one part of life in the other, and segmentation hypothesis refers to life and job satisfaction being not correlated as people keep their work and non-work satisfaction separate from each other. Sirgy (2012) emphasizes that job satisfaction not only spills over from work to life satisfaction vertically but also horizontally to adjacent life domains such as family, social, financial, leisure, and community life. He adds that the extent of spillover from job satisfaction to life satisfaction (bottom-up spillover) and to other life domains (horizontal spillover) is moderated by job involvement, meaning that more involved employees are more likely to experience greater spillover than those who are less involved. Steiner and Truxillo (1987) indicate that spillover model applies to extrinsic outcomes, which individuals can take home with them such as pay or the prestige of the institution or position: if satisfied with these outcomes at work, individuals are satisfied when they take them home as well. Referring to intrinsic outcomes (which are only enjoyed while at work such as job autonomy), they state that an employee must place great importance on work in the overall life context, otherwise the level of satisfaction with intrinsic outcomes are less related to life satisfaction. In their research, Judge and Watanabe (1993) find a relatively strong relationship between life and job satisfaction cross-sectionally using a casual model, yet this relationship weakens over a five year period, especially regarding the impact of job satisfaction on life satisfaction. Bakan and Büyükbeşe (2013) state that there is a significant relationship between employees' income level and job satisfaction yet the direction of the causality needs to be studied more. Their research undertaken in a British company demonstrates that job satisfaction components such as social satisfaction, work satisfaction, satisfaction with compensation, promotion and supervisor are positively correlated with income.

In the Turkish context, Köksal (2014) finds that spillover hypothesis explains the relationship between life and job satisfaction at 56 percent, which is 24 percent for compensation hypothesis, and 20 percent for segmentation hypothesis. He further argues that the relationship between life and job satisfaction can be discussed solely by considering individual differences. Bülbül and Giray (2012) present a moderate relationship between life 
Ermiş-Mert, A. (2020), “A Multivariate Investigation of Overall Happiness, Job Satisfaction and Income Satisfaction of Women and Men in Turkey", Sosyoekonomi, Vol. 28(44), 11-26.

and job satisfaction in Turkey (consistent with the spillover hypothesis), which changes greatly according to demographic differences, and is considerably higher for women as they find that women's happiness levels are extended to their professional lives. Aydintan and Koç (2016) underline that teachers' job satisfaction is significantly influential on their life satisfaction whereas the intensity of the relationship varies according to sociodemographic features and subject area of the teachers in Turkey.

In this article, after the data set and methodology used in the paper are introduced, firstly, a descriptive comparison of women's and men's happiness patterns regarding life, job and income will be presented. Secondly, the correlation between these three components of happiness will be measured for women and men using Spearman's rank-order correlation (Spearman, 1904). The Life Satisfaction Survey used in the analysis (TurkStat, 2016) has no corresponding variables for measuring whether women's expectations are lower in paid work relative to men. However, especially the association between women's job and income satisfaction will provide an indirect understanding of their expectations exclusively related to their earnings. Thirdly, the multivariate probit regression analysis results will be presented, which will examine the impact of various independent variables on the three components of happiness for women and men in paid work. Moreover, the correlation coefficients in this analysis will confirm whether and to what extent there is spillover from life to job, job to income, and life to income satisfaction of working women and men in Turkey.

Investigating happiness in the Turkish context is important as Turkey has the fifth lowest life satisfaction rate among OECD countries (OECD, 2015). Therefore, this paper contributes to the literature of gender, work and happiness in Turkey firstly by investigating spillover hypothesis for women's and men's happiness levels in life, at their jobs and concerning their income, the latter being not commonly used as a separate means. Also, the concomitant examination of components affecting these means of happiness further contribute to the discussion. Findings are primarily expected to challenge the arguments stating that women give less importance to financial aspects of their jobs than men while they value interpersonal relations at work more (Graves \& Powell, 2011; Zou, 2015).

\section{Data and Methodology}

In this study, Life Satisfaction Survey (LFS) (TurkStat, 2016) is used for analysis. There is only cross-sectional data (in terms of secondary data sources) available on happiness in Turkey, LFS is the most relevant microdata for the analyses of this paper, and during the time phrase this study started to be conducted, the 2016 dataset was the latest available. This survey measures individuals' happiness, hopefulness and satisfaction levels regarding different spheres of life and public services (TurkStat, 2016). It includes relevant demographic questions and questions related to happiness/satisfaction levels of individuals regarding life, job and income. Life satisfaction corresponds to happiness based on the question of "Considering your life as a whole, how happy are you?", whereas job and income satisfaction levels are determined based on the questions of "Are you content (satisfied) with your job/income?" as directed in the questionnaire. 
After the descriptive statistics and Spearman's rank-order correlation (Spearman, 1904) are discussed, the multivariate probit regression model (Cappellari \& Jenkins, 2003) will be presented for the main analysis. The three dependent variables in this model are "being happy with one's life", "being satisfied with one's job" and "being satisfied with one's income". For this model, the dependent variables need to be binary. Therefore, based on the Likert scale (1 to 5) measures of these means of happiness, binary dummy variables are created as "satisfied/happy", which include "satisfied/happy or very satisfied/very happy", and "not satisfied/not happy" referring to "neutral, unsatisfied/unhappy or highly unsatisfied/highly unhappy". This is because the main goal is to examine happy or very happy women and men in life/at work/in terms of income, relative to all other statuses of happiness concerning these three components.

As stated, the 5-point Likert scale statements that are operationalized as the three dependent variables of the model include negative (unsatisfied and very unsatisfied) and positive (satisfied and very satisfied) components as well the neutral category of "neither satisfied nor dissatisfied". This could imply that implementing three separate ordered logistic regression models can be an ideal method in this context. However, multivariate probit model is chosen as the main method of the study in accordance with the aim of measuring the impact of independent variables on three binary dependent variables simultaneously, and confirming the levels of association between the dependent variables with the rho values presented in the model.

Independent variables in the multivariate probit regression model, all of which are categorical variables (binary, nominal and ordinal), comprise a) demographic variables: age categories, educational level and marital status, b) work-related variables: status at work (employee, employer, self-employed or unpaid family worker), whether satisfied with workplace relations, working in private/public sector, whether promoted/received a pay rise in the past year, and c) value-based components that include the questions on how important other people's views separately on job and income are. In the multivariate probit model, three individual probit models will be simultaneously conducted together with the presentation of the pairwise correlations between the dependent variables. Finally, the postestimation predictions will show the joint probabilities of all dependent variables being negative (neutral, unsatisfied or highly unsatisfied) and positive (satisfied or very satisfied) for women and men (Cappellari \& Jenkins 2003).

For organizational and business research, self-report measures (e.g. in self-rated satisfaction/happiness levels) are claimed to inflate the relationship between variables, also to result in common method bias (Conway \& Lance, 2010). Hence, in this section, the issues of common methods bias (CMB) as well as common methods variance (CMV) will be acknowledged. To provide detailed description of these concepts, Meade et al. (2007) state that CMV suggests variance in observed scores to be somewhat related to a methods effect, while CMB can be described as the extent to which correlations are inflated because of a methods effect. 
In the literature, self-reports in studies focusing on particularly job satisfaction are considered appropriate in terms of methodology while other methods could be more valid for measuring job characteristics or performance (Chan, 2009; Conway \& Lance, 2010). Considering that this study mainly focuses on measuring subjective levels of satisfaction, analysing self-reports is indeed a valid method for examining individuals' claims regarding their own happiness in different spheres of life. In addition, many scholars are not pessimistic about the potential impact of CMB and CMV. Fuller et al. (2016) indicate that potential problems with $\mathrm{CMB}$ or CMV have been a concern in business research yet almost no one reaches results that are problematic. Lance et al. (2010) state that common method effects do not appear to be as large as to create a remarkable threat to organizational research, specifically when considering the neutralizing effects of measurement error. Meade et al. (2017) also underline that even a significant effect of CMV may not be necessarily an issue if the inflation in the correlations among measures is found to a small extent.

\section{Results and Discussions}

As stated earlier, there are studies presenting differences between women's and men's job satisfaction levels in different contexts and occupations. These arguments mostly refer to women's satisfaction levels at work being higher than men (Kim, 2005; Okpara et al., 2005; Miao et al., 2017). However, descriptive statistics (Figure 1) demonstrate highly similar results for women and men in Turkey overall not only in terms of job satisfaction but also regarding life and income satisfaction. Being happy (in life/at work/with income) represents those who responded "happy/satisfied" or "very happy/very satisfied" in relevant questions. Figure 1 presents moderate life and income satisfaction levels for both working women and men in Turkey, while job satisfaction levels are fairly high. As the figure displays the overall happiness levels of working individuals, the rates are 63,5 percent for women and 58,3 percent for men regardless of working status. For working individuals, women's rate of being "very happy" overall is 8,0 percent, which is 7,4 percent for men. 8,0 percent of women claim that they are "very satisfied" with their jobs, men did so with 6,4 percent. Finally, 2,0 percent of women and 1,6 percent of men state that they are "very happy" with their income (TurkStat, 2016). 


\section{Figure: 1}

Women's and Men's Rates of Being Happy or Very Happy in Life, at Work and with Their Income

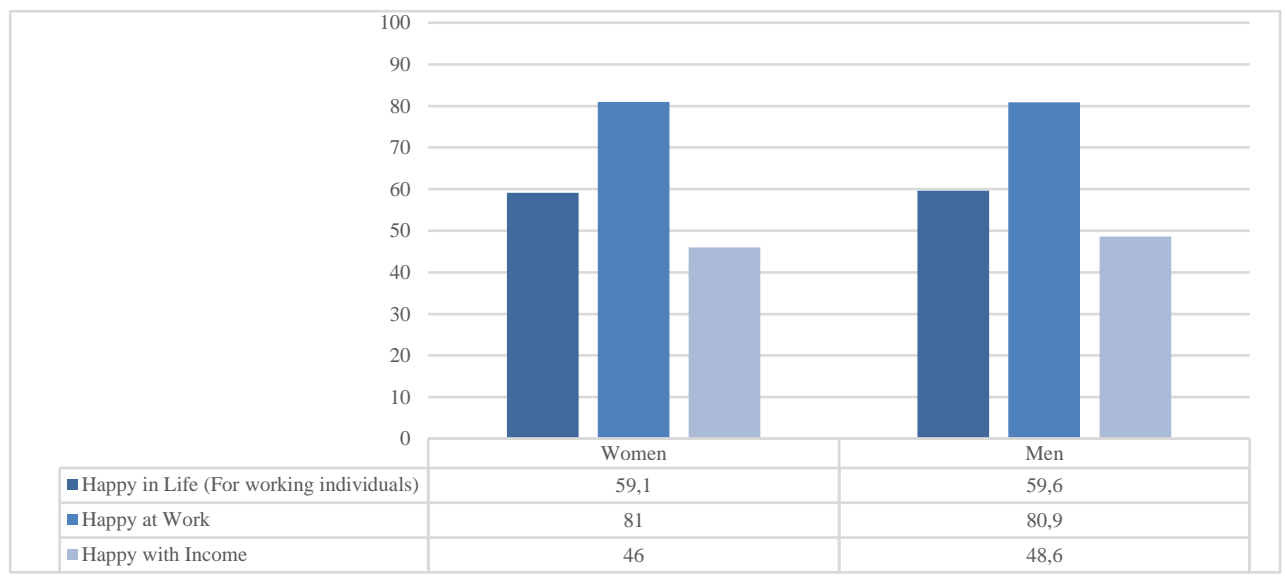

Source: Turkish Statistical Institute, 2016.

While life, job and income satisfaction rates are highly similar for women and men in Turkey as stated, the same pattern could be seen in some other contexts as well. In their discussion paper, Redmond and McGuiness (2019) find that on a scale from 0 to 10 ( 0 being the least, 10 being the most satisfied), average job satisfaction score is 7.03 for women and 6.98 for men in European Union member states. Regarding income satisfaction, the Eurostat report edited by Mercy et al. (2015) shows that in European Union member states, women's financial satisfaction is high with a percentage of 13,0, medium with 48,3 percent, and low with 38,7 percent, while the rates are 13,3 percent, 50,4 percent and 36,3 percent for men in the same order.

In Table 1, Spearman's correlation coefficients present the association between life and job, life and income as well as job and income satisfaction of women and men in Turkey.

Table: 1

Spearman's Correlation Coefficients

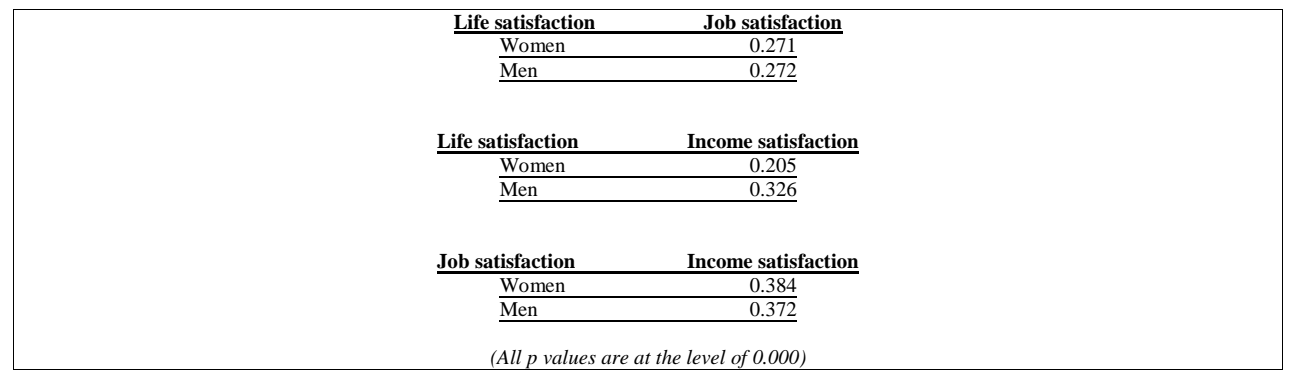

Source: Turkish Statistical Institute, 2016. 
As seen, life satisfaction is positively correlated with job and income satisfaction for both women and men, and there is also a positive correlation between women's and men's job and income satisfaction, all of which are on a weak to moderate level yet statistically significant. For men, the correlation between overall happiness and job satisfaction has the lowest (yet positive) value, whereas for women the lowest (though positive) correlation is observed between their overall happiness and income satisfaction. For both women and men, the correlation between job satisfaction and income satisfaction has the highest value, which is slightly stronger for women. These findings support the spillover hypothesis, which claims that life and job satisfaction are positively correlated (income satisfaction included in this context) as these components affect each other (Strauser, 2014). A Eurostat report shows that in European Union member states, the correlation is 0.472 between life satisfaction and job satisfaction, 0.634 between life satisfaction and financial satisfaction, and 0.421 between job satisfaction and financial satisfaction regardless of gender (Eurostat, 2013). The rho values in EU-28 countries (regardless of gender) are higher than Turkey (separately for women and men) for all correlation coefficients, which are at a more moderate level, life and financial satisfaction presenting the strongest association (similar for women and for men in Turkey).

As presented in Table 2, the multivariate probit regression analysis model (Cappellari \& Jenkins, 2003) investigates the impact of various demographic and happiness-related components on women's and men's satisfaction in life, at work and with their income. In addition, rho values re-evaluate the direction and magnitude of the correlation between these means to confirm the spillover hypothesis in the Turkish context.

Table: 2

Multivariate Probit Regression Analysis

Women's and Men's Life (Overall Happiness), Job and Income Satisfaction

\begin{tabular}{|c|c|c|c|}
\hline & Life satisfaction & Job satisfaction & Income satisfaction \\
\hline \multirow{2}{*}{\multicolumn{4}{|c|}{$\begin{array}{l}\text { Women (in paid work) } \\
\text { Age }\end{array}$}} \\
\hline & & & \\
\hline \multicolumn{4}{|l|}{ 15-24 (Reference category) } \\
\hline $25-34$ & $-.16(.15)$ & $-.20(.17)$ & $.00(.15)$ \\
\hline $35-44$ & $-.39(.16) * *$ & $-.25(.18)$ & $-.08(.15)$ \\
\hline $45-54$ & $-.45(.17)^{* *}$ & $-.25(.20)$ & $-.09(.17)$ \\
\hline $55-64$ & $-.08(.21)$ & $-.24(.23)$ & $.00(.21)$ \\
\hline $65+$ & $.04(.37)$ & $-.36(.39)$ & $-.11(.35)$ \\
\hline \multicolumn{4}{|l|}{ Educational level } \\
\hline Highly educated (Ref. cat.) & & & \\
\hline Medium educated & $-.18(.13)$ & $.10(.15)$ & $.14(.13)$ \\
\hline Low educated & $-.17(.12)$ & $.05(.14)$ & $.16(.12)$ \\
\hline \multicolumn{4}{|l|}{ Marital Status } \\
\hline$\overline{\text { Married (Ref. cat.) }}$ & & & \\
\hline Single & $-.34(.12)^{* *}$ & $-.41(.14)^{* *}$ & $-.09(.12)$ \\
\hline Divorced & $-.63(.17) * * *$ & $-.24(.19)$ & $-.52(.17)^{* * *}$ \\
\hline Widowed & $-.93(.23) * * *$ & $.01(.28)$ & $.13(.22)$ \\
\hline \multicolumn{4}{|l|}{ Status at work } \\
\hline$\overline{\text { Employee (Ref. cat.) }}$ & & & \\
\hline Employer & $-.39(.29)$ & $-.11(.33)$ & $-.01(.30)$ \\
\hline Self-employed & $.11(.16)$ & $-.40(.18) *$ & $-.20(.16)$ \\
\hline Unpaid family worker & $.28(.12)^{*}$ & $-.43(.13) * * *$ & $-.39(.12)^{* * * *}$ \\
\hline$\underline{\text { Satisfaction with workplace relations }}$ & & & \\
\hline Satisfied (Ref. cat.: Not satisfied) & $.80(.13)^{* * * *}$ & $1.20(.13)^{* * * *}$ & $.85(.13)^{* * * *}$ \\
\hline Private/public sector & & & \\
\hline Public Sector (Ref. cat.: Private sector) & $.10(.13)$ & $.14(.15)$ & $.22(.12)$ \\
\hline Promotion in the past year & & & \\
\hline Yes (Ref. cat.: No) & $-.46(.24)$ & $-.13(.28)$ & $-.21(.24)$ \\
\hline
\end{tabular}


Ermiş-Mert, A. (2020), "A Multivariate Investigation of Overall Happiness, Job Satisfaction and Income Satisfaction of Women and Men in Turkey", Sosyoekonomi, Vol. 28(44), 11-26.

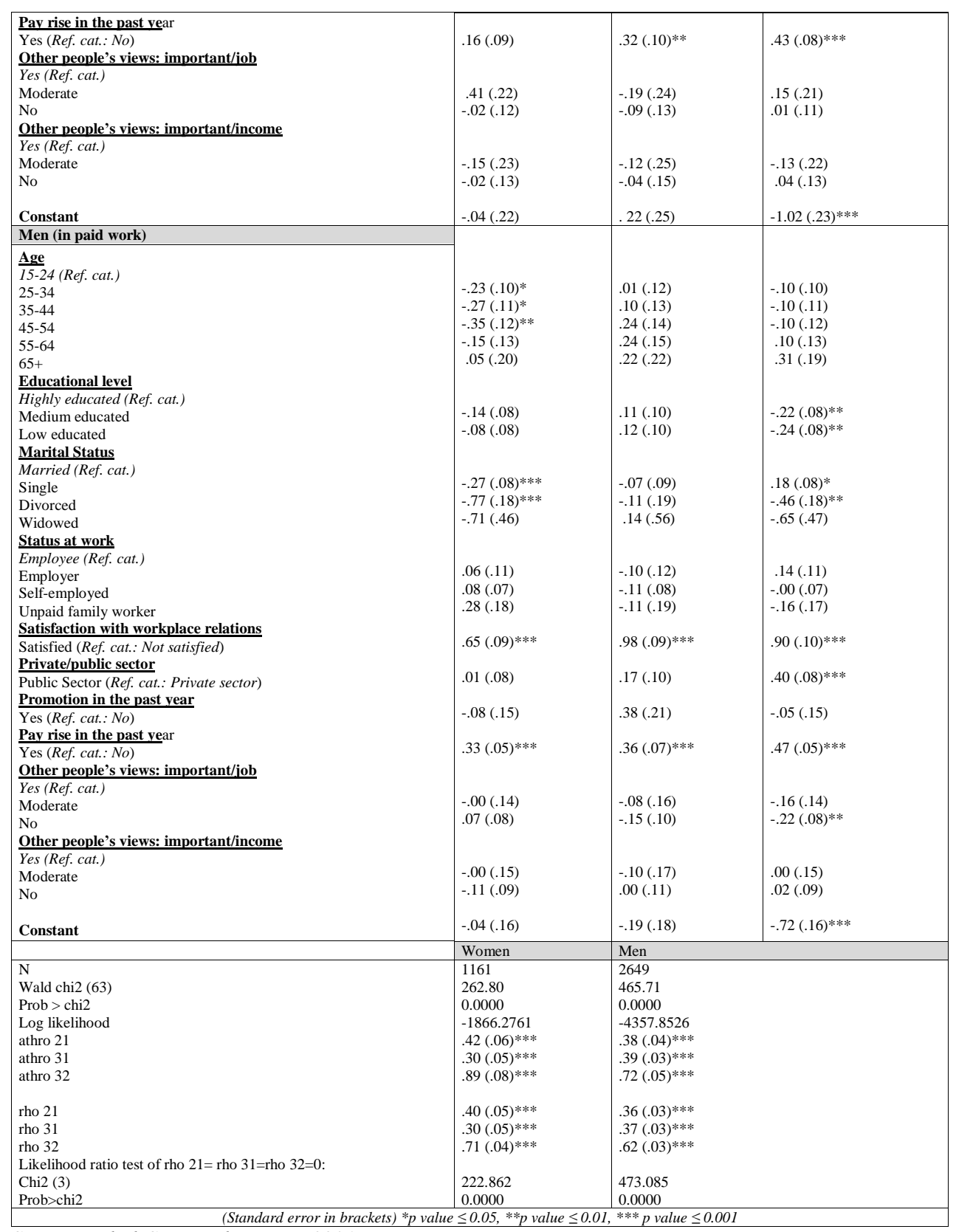

Source: Turkish Statistical Institute, 2016. 
Ermiş-Mert, A. (2020), “A Multivariate Investigation of Overall Happiness, Job Satisfaction and Income Satisfaction of Women and Men in Turkey", Sosyoekonomi, Vol. 28(44), 11-26.

To evaluate the impact of age on life, job and income satisfaction based on statistically significant findings, relative to the age group of 15 to 24 , women aged 35 to 44 and 45 to 54 are less likely to report high levels of life satisfaction. The same pattern exists for men regarding life satisfaction for these two age groups, and additionally, men aged 25 to 34 are less likely compared to men who are between 15 and 24 years old to claim they are happy or very happy with their lives.

The impact of educational level on all three components of happiness is not statistically significant for women. For men, increasing educational level statistically significantly rises the probability to report high levels of income satisfaction.

Single, divorced and widowed women are statistically significantly less likely to report they are happy or very happy in life relative to married women. As single women are less likely to claim that they are happy or very happy with their jobs relative to married women on a statistically significant level, the same pattern exists for divorced women concerning income satisfaction. Single and divorced men are less likely to report high levels of life satisfaction relative to married men. While single men are more likely to have high income satisfaction relative to married men, divorced men are statistically significantly less likely to be satisfied or very satisfied with their income. On a related note, considering the double burden women struggle with, comparing the impact of number and ages of children on women's and men's life and job satisfaction alongside with marital status would have contributed to the analysis immensely. However, no variable associated with having children is included in the microdata examined in this article.

Women, who are unpaid family workers, are more likely than employees (wage and salaried workers) to report high levels of overall life satisfaction. Unpaid family workers, relative to employees, are statistically significantly less likely to claim job satisfaction (alongside with self-employed women) and income satisfaction as anticipated, considering their lack of autonomy at work and in relation to mostly having limited or no income. In terms of employment status and happiness, Çevik and Korkmaz (2014) find that being an employer has no effect on life satisfaction in Turkey, it has a meaningful and direct relationship with job satisfaction, and being an unpaid family worker has a positive impact on life satisfaction. The first and last findings highlighted are paralell to the results presented in Table 2 for women. Status at work has no statistical significant impact on the likelihood to have high levels of life, job or income satisfaction for men.

For both women and men in Turkey, being satisfied with workplace relations have a statistically significantly positive impact on life, job and income satisfaction levels. Women and men reporting that they are satisfied with their workplace relations, relative to those who are not, are more likely to claim high levels of satisfaction in these three spheres of life. There are studies that refer to workplace relations as one of the less significant determinants of job satisfaction in comparison to other components such as intrinsic motivation and relations with management (Westover \& Taylor, 2010), while research conducted in the Turkish context support the positive and significant impact of workplace relations on job 
satisfaction and diminishing turnover intention (Çetinkaya-Bozkurt et al., 2016), and their partial role in being a medium between life and job satisfaction (Özyer et al., 2015).

Özsoy et al. (2014) find that employees in public sector are more satisfied with their lives and jobs than those in private sector in Turkey. The findings of this research show that men working in public sector relative to private sector are statistically significantly more likely to report they are "satisfied or very satisfied" with their income, whereas all results for women and other results for men are not statistically significant.

Lup (2018) finds that promotion to management increases job satisfaction for men but not for women, and after women are promoted to higher-level managerial positions, their job satisfaction levels even begin to decrease. However, there is no result in this particular study to compare this finding with the Turkish context as being promoted in the past year has no statistical significant impact on women's and men's likelihood to claim high levels of happiness in life, at work and with their income. When it comes to pay rise in the past year, the pattern changes. Men who report to have received a pay rise in the past year are statistically significantly more like to report being happy or very happy in life, at their jobs and with their income. For women, job and income satisfaction levels are affected by pay rise in the past year positively and statistically significantly. Regarding the impact of improved income on happiness, there are contrasting findings in the literature. Young et al. (2014) find a negative impact of raising income on life and job satisfaction, which they associate with the increasing problems that exacerbate with more money as well as with the argument that once a goal is met, people move on to another, and this cycle adds up to discontent. They add that perceived financial wellness instead of the amount of money is more significantly related to life satisfaction. There are also arguments referring to pay as one of the less, least or even non-important job characteristics in terms of its low correlation to job satisfaction (Clark, 1998; Argyle, 2013). However, both Spearman's correlation coefficients and multivariate probit regression analysis in this study demonstrate a distinct picture for the case of Turkey. As the relationship between job and income satisfaction is found to be meaningful in this article (and the strongest association is seen for women's job and income satisfaction), Eren and Aş1c1 (2017) also find that although it is not observed in their macro data analysis, there is a meaningful and positive relationship between happiness and income.

Life, job and income satisfaction of women and men are expected to be related to other people's opinions regarding their job and income to a certain extent, which posits a somewhat reverse relativity. The only statistically significant result displays that men who argue that other people's views on their job are not important relative to men who claim the opposite are less likely to report high levels of income satisfaction.

The rho values in the multivariate probit regression model (all statistically significant), as Spearman's correlation coefficients have also shown, present a meaningful association between life and job, life and income as well as job and income satisfaction for women and men. The coefficients for the correlation between women's and men's life and job satisfaction are .40 and .36 respectively, and .30 (women) and .37 (men) between life 
Ermiş-Mert, A. (2020), “A Multivariate Investigation of Overall Happiness, Job Satisfaction and Income Satisfaction of Women and Men in Turkey", Sosyoekonomi, Vol. 28(44), 11-26.

and income satisfaction. The correlation coefficient of men's job and income satisfaction is .62. As all of these values are at a moderate level, the coefficient for women's job and income satisfaction (.72) stands at a strong level, and this result is consistent with the Spearman's correlation coefficient. These findings support the spillover hypothesis for all three means of happiness investigated in this article.

Although spillover pattern is an anticipated result for individuals' happiness in different spheres of life, the main point in the context of this study is the strength of the association between these three components of happiness separately for women and men. The finding that the correlation between women's job satisfaction and income satisfaction is the highest could challenge the arguments that women's job satisfaction is not significantly affected by pay (Leontaridi \& Sloane, 2004; Huang \& Gamble, 2015). Graves and Powell (2018: 83) suggest that pay is more important for men than women, and women are less concerned about the financial side of their job and more so for other aspects of it including interpersonal relations, also workplace relations. Zou (2015) has a similar finding that men value pay more, and having "friendly people to work with" is among the job aspects women value. However, for the Turkish case, this study highlights that for both women and men satisfactory workplace relations statistically significantly increase the likelihood to have high levels of job satisfaction, and the positive correlation between women's job satisfaction and income satisfaction levels are even slightly higher than that of men.

Finally, the post-estimation analysis demonstrates that the joint predicted probability of women's overall happiness, job satisfaction and income satisfaction to be high (satisfied/happy or very satisfied/very happy) is 31,7 percent. The probability of none of these three components to be high is 11,9 percent for women. The predicted probabilities are 33,8 percent (joint predicted probability of overall happiness, job satisfaction and income satisfaction to be high) and 11,2 percent (joint predicted probability of none of these means of happiness to be high) for men.

\section{Conclusion}

This article investigated working women's and men's overall happiness, job satisfaction and income satisfaction levels, the means that influence these and the correlation between them. Firstly, the findings underlined that overall, working women's and men's happiness, job satisfaction and income satisfaction levels are similar in Turkey. Yet, there are common as well as separate indicators affecting these components. For both women and men, satisfaction with workplace relations has a statistically significant positive impact on their happiness in life, at work and regarding their income. While getting a pay rise in the previous year increases men's likelihood to claim high levels of happiness for all three means, the same effect is observed for women's job and income satisfaction. Being an unpaid family worker relative to an employee sharply decreases the likelihood to have high levels of job and income satisfaction for women, which is expected to be related to the lack of occupational autonomy, career prospects and mostly income in the former type of employment. In addition, for men, income satisfaction is found more likely to be high in the public sector relative to the private sector. 
Regarding the association between the components of happiness, both the Spearman's rank-order correlation analysis and correlation coefficients in the multivariate probit regression model demonstrate a spillover pattern between life and job, life and income as well as job and income satisfaction of women and men in paid work. There was no direct means of measurement available in the data to evaluate whether relativity in pay affects income satisfaction or whether women's expectations from their jobs are lower than men. However, while the latter is associated with the argument that women have higher job satisfaction levels (allegedly due to having lower expectations), no such difference is found in Turkey similar to the European Union countries as presented. Also, the strongest correlation is seen between women's job satisfaction and income satisfaction levels. Therefore, there is an indication that women's expectations at work, in terms of their financial gains to say the least, could not be visibly weaker than men.

This article has shown that there are common as well as diverse components that affect the three means of happiness for women and men. The findings of this study have also shown that the job satisfaction of working women in Turkey is positively and meaningfully affected by increased pay. In addition, the strongest association has been found between women's job and income satisfaction. These results underline the importance of financial motivation for women in relation to being fulfilled at work. Therefore, challenging the gender pay gap in all segments of the labour market, and providing women equal working conditions and benefits need to be among the focal aims of policy makers. This is important not only for the well-being of women who are currently employed, but also for those who withdraw from the job market or do not participate in the first place due to low wages that mainly do not compensate for overall life costs or for contributing to childcare expenses.

As per further research, we need to highlight "relativity" and "subjectivity" in individuals' statements regarding their happiness in the Turkish context. In addition, future studies on Turkey could elevate the discussions on life, job and income satisfaction by developing longitudinal measures, which take variations in different life stages of individuals into account as suggested by Rain et al. (1991), as well as by integrating causality into the framework.

\section{References}

Argyle, M. (2013), The Psychology of Happiness, Routledge.

Aydıntan, B. \& H. Koç (2016), "The Relationship between Job Satisfaction and Life Satisfaction: An Empirical Study on Teachers", International Journal of Business and Social Science, 7(10), 72-80.

Bakan, İ. \& T. Büyükbeşe (2013), “The Relationship between Employees' Income Level and Employee Job Satisfaction: An Empirical Study”, International Journal of Business and Social Science, 4(7), 18-25.

Bülbül, Ş. \& S. Giray (2012), "İş ve Özel Yaşam (İş Dışı Yaşam) Memnuniyeti Arasındaki İlişki Yapısının Doğrusal Olmayan Kanonik Korelasyon Analizi ile İncelenmesi”, Anadolu Üniversitesi Sosyal Bilimler Dergisi, 12(4), 101-14. 
Ermiş-Mert, A. (2020), “A Multivariate Investigation of Overall Happiness, Job Satisfaction and Income Satisfaction of Women and Men in Turkey", Sosyoekonomi, Vol. 28(44), 11-26.

Cappellari, L. \& S.P. Jenkins (2003), "Multivariate Probit Regression Using Simulated Maximum Likelihood", The Stata Journal, 3(3), 278-94.

Chan, D. (2008), “So Why Ask Me? Are Self-Report Data Really That Bad?”, in: C.E. Lance \& R.J. Vandenberg (eds.), Statistical and Methodological Myths and Urban Legends: Doctrine, Verity, and Fable in the Organizational and Social Sciences, New York: Routledge, 30936.

Chiu, C. (1998), "Do Professional Women Have Lower Job Satisfaction than Professional Men? Lawyers As A Case Study", Sex Roles, 38(7-8), 521-37.

Clark, A. (1997), “Job satisfaction and Gender: Why Are Women So Happy at Work?”, Labour Economics, 4(4), 341-72.

Clark, A. (1998), "Measures of Job Satisfaction: What Makes a Good Job? Evidence from OECD Countries", OECD Labour Market and Social Policy Occasional Papers, No. 34.13 August 1998. Paris: OECD Publishing, <http://dx.doi.org/10.1787/670570634774>.

Conway, J.M. \& C.E. Lance (2010), "What Reviewers Should Expect from Authors regarding Common Method Bias in Organizational Research", Journal of Business and Psychology, 25(3), 325-34.

Çetinkaya-Bozkurt, Ö. \& E.B. Bulgurcu-Gürel \& A.M. Alparslan (2016), "Üniversite Çalışanlarında İş Yeri Arkadaşlığının İş Tatmini ve İşten Ayrılma Niyeti Üzerine Etkileri”, Akademik Sosyal Araştırmalar Dergisi, 4(37), 111-26.

Çevik, N.K. \& O. Korkmaz (2014), “Türkiye'de Yaşam Doyumu ve İş Doyumu Arasındaki İlişkinin İki Değişkenli Sıralı Probit Model Analizi”, Niğde Üniversitesi İktisadi ve İdari Bilimler Fakültesi Dergisi, 7(1), 126-45.

Demirel, E.T. \& A. Yıldırım (2015), "Ücret Tatmininin Yaşam Tatminini Belirleyici Etkisi Var M1? Elazığ Banka Çalışanları Örneği”, Fırat Üniversitesi Sosyal Bilimler Dergisi, 25(2), 13354.

Dolan, S.L. \& E. Gosselin (2000), "Job Satisfaction and Life Satisfaction: Analysis of a Reciprocal Model with Social Demographic Moderators", Working Paper, <http://hdl.handle.net/10230/1225>, 09.08.2018.

Eren, K.A. \& A.A. Aşı1 (2017), "The Determinants of Happiness in Turkey: Evidence from CityLevel Data", Journal of Happiness Studies, 18(3), 647-69.

Eurostat (2013), Analysis and Preparation for the Dissemination of the Data on Well-Being and Quality of Life of Individuals Living in the EU, Eurostat, European Commission, <https://ec.europa.eu/eurostat/documents/1012329/1012401/2013+Module+assessment.p df $>$, 04.01.2020.

Fuller, C.M. \& M.J. Simmering \& G. Atinc \& Y. Atinc \& B.J. Babin (2016), "Common Methods Variance Detection in Business Research", Journal of Business Research, 69(8), 3192-8.

Graves, L.M. \& G.N. Powell (2018), "Making Employment Decisions”, in: G.N. Powell (ed.), Women and Men in Management, Sage Publications, 74-102.

Groot, W. \& H.M. van den Brink (2000), "Job Satisfaction, Wages and Allocation of Men and Women", in: M.J. Sirgy \& D. Rahtz \& A.C. Samli (eds.), Advances in Quality of Life Theory and Research, Dordrecht: Springer, 111-28.

Huang, Q. \& J. Gamble (2015), "Social Expectations, Gender and Job Satisfaction: Front-Line Employees in China's Retail Sector”, Human Resource Management Journal, 25(3), 331-47. 
Judge, T.A. \& S. Watanabe (1993), “Another Look at the Job Satisfaction-Life Satisfaction Relationship", Journal of Applied Psychology, 78(6), 939-48.

Kim, S. (2005), "Gender Differences in the Job Satisfaction of Public Employees: A Study of Seoul Metropolitan Government, Korea", Sex Roles, 52(9-10), 667-81.

Köksal, O. (2014), “İş Doyumu ve Yaşam Doyumu Arasındaki İlişkide Bireysel Farklılıklar”, İş ve Insan Dergisi, 1(1), 53-62.

Lance, C.E. \& B. Dawson \& D. Birkelbach \& B.J. Hoffman (2010), "Method Effects, Measurement Error, and Substantive Conclusions", Organizational Research Methods, 13(3), 435-55.

Leontaridi, R.M. \& P.J. Sloane (2004), "Low Pay, Higher Pay, Earnings Mobility and Job Satisfaction in Britain", in: D. Meulders \& R. Plasman \& F. Rycx (eds.), Minimum Wages, Low Pay and Unemployment, London: Palgrave Macmillan, 87-140.

Loewe, N. \& M. Bagherzadeh \& L. Araya-Castillo \& C. Thieme \& J.M. Batista-Foguet (2014), "Life Domain Satisfactions as Predictors of Overall Life Satisfaction among Workers: Evidence from Chile", Social Indicators Research, 118(1), 71-86.

Lup, D. (2018), "Something to Celebrate (or Not): The Differing Impact of Promotion to Manager on the Job Satisfaction of Women and Men", Work, Employment and Society, 32(2), 407-25.

Mayraz, G. \& G.G. Wagner \& J. Schupp (2009), "Life Satisfaction and Relative Income-Perceptions and Evidence", IZA Discussion Paper Series, No. 4390, <https://dnb.info/997350601/34>, 23.01.2019.

Meade, A.W. \& A.M. Watson \& C.M. Kroustalis (2007), "Assessing Common Methods Bias in Organizational Research", 22nd Annual Meeting of the Society for Industrial and Organizational Psychology, April 2007, New York, 1-10.

Medvedev, O.N. \& C.E. Landhuis (2018), "Exploring constructs of well-being, happiness and quality of life", PeerJ, 6, e4903, <https://www.ncbi.nlm.nih.gov/pmc/articles/PMC5985772/pdf/peerj-06-4903.pdf>, 12.01.2020.

Mercy, J.L. \& A. Litwinska \& D. Dupré \& S. Clarke \& G.A. Ivan \& C. Stewart (eds.) (2015), Quality of Life: Fact and Views, EuroStat Statistical Books, EuroStat, <https://ec.europa.eu/eurostat/documents/3217494/6856423/KS-05-14-073-EN-N/>, 04.01.2020.

Miao, Y. \& L. Li \& Y. Bian (2017), “Gender Differences in Job Quality and Job Satisfaction among Doctors in Rural Western China", BMC Health Services Research, 17, No. 848, <http://doi.org/10.1186/s12913-017-2786-y>.

Ng, Y.K. (2015), Happiness, Life Satisfaction, or Subjective Well-being? A Measurement and Moral Philosophical Perspective, Nanyang Technological University, <https://www.ntu.edu.sg/home/ykng/Happiness,LS,\%20SWB-2015.pdf>, 12.01.2020.

O'Donnell, P. (2015), The Effect of Income and Working Conditions on Job Satisfaction, The College of New Jersey, <https://business.tcnj.edu/files/2015/08/ECO-495-2015_PatrickODonnell.pdf $>$, 05.06.2018.

OECD (2015), How's Life? 2015: Measuring Well-being, Paris: OECD Publishing, <http://dx.doi.org/10.1787/how_life-2015-en>.

Okpara, J.O. \& M. Squillace \& E.A. Erondu (2005), "Gender Differences and Job Satisfaction: A Study of University Teachers in the United States", Women in Management Review, 20(3), 177-90. 
Özsoy, E. \& O. Uslu \& O. Öztürk (2014), "Who are Happier at Work and in Life? Public Sector versus Private Sector: A Research on Turkish Employees", International Journal of Recent Advances in Organizational Behaviour and Decision Sciences, 1(2), 148-60.

Özyer, K. \& E. Irk \& S. Anaç (2015), "İş Tatmini ve Yaşam Tatmini İlişkisinde İş Arkadaşlı̆̆ının Arac1lık Rolü”, Cumhuriyet Üniversitesi İktisadi ve İdari Bilimler Dergisi, 16(1), 261-78.

Rain, J.S. \& I.M. Lane \& D.D. Steiner (1991), “A Current Look at the Job Satisfaction/Life Satisfaction Relationship: Review and Future Considerations", Human Relations, 44(3), 287-307.

Redmond, P. \& S. McGuinness (2019), "Explaining the Gender Gap in Job Satisfaction”, IZA Institute of Labor Economics Discussion Paper Series, No. 12703, <http://ftp.iza.org/dp12703.pdf>, 04.01.2020.

Sirgy, M.J. (2012), The Psychology of Quality of Life: Hedonic Well-Being, Life Satisfaction, and Eudaimonia (2nd ed.), Dordrecht \& New York: Springer.

Sousa-Poza, A. \& A.A. Sousa-Poza (2000), "Taking Another Look at the Gender/Job-Satisfaction Paradox", Kyklos, 53(2), 135-52.

Spearman, C.E. (1904), "The Proof and Measurement of Association between Two Things", American Journal of Psychology, 15, 72-101.

Steiner, D.D. \& D.M. Truxillo (1987), “Another Look at the Job Satisfaction-Life Satisfaction Relationship: A Test of the Disaggregation Hypothesis", Journal of Organizational Behavior, 8(1), 71-7.

Strauser, D.R. (2014), Career Development, Employment, and Disability in Rehabilitation: From Theory to Practice, Springer Publishing Company.

Turkish Statistical Institute (2016), Life Satisfaction Survey.

Unanue, W. \& M.E. Gómez \& D. Cortez \& J.C. Oyanedel \& A. Mendiburo-Seguel (2017), "Revisiting the Link Between Job Satisfaction and Life Satisfaction: The Role of Basic Psychological Needs", Frontiers in Psychology, 8, 680.

Westover, J.H. \& J. Taylor (2010), "International Differences in Job Satisfaction: The Effects of Public Service Motivation, Rewards and Work Relations", International Journal of Productivity and Performance Management, 59(8), 811-28.

Young, L. \& M. Milner \& D. Edmunds \& G. Pentsil \& M. Broman (2014), “The Tenuous Relationship between Salary and Satisfaction”, Journal of Behavioral Studies in Business, 7, 1-9.

Zou, M. (2015), “Gender, Work Orientations and Job Satisfaction”, Work, Employment and Society, 29(1), 3-22. 